Herz 2020 · 45:663-667

https://doi.org/10.1007/s00059-020-04991-3

Received: 25 August 2020

Accepted: 8 September 2020

Published online: 7 October 2020

(c) Springer Medizin Verlag $\mathrm{GmbH}$, ein Teil von Springer Nature 2020

\title{
Reduced rate of admissions for acute coronary syndromes during the COVID-19 pandemic: an observational analysis from a tertiary hospital in Germany
}

\section{Introduction}

The ongoing Coronavirus disease (COVID-19) pandemic caused by severe acute respiratory syndrome Coronavirus 2 (SARS-COV-2), has been associated with an increased death toll worldwide. Due to high infectiousness and initial reports of severe morbidity and mortality associated with the disease, virtually every country in the world, including Germany, has taken serious preventive measures, including home isolations, limitations and monitoring of transportation and workplaces [1].

A relevant part of the healthcare system has also been redirected in management of COVID-19 cases. As a result of this and as a measure to avoid in-hospital contagion, elective non-urgent procedures and hospital admissions were drastically reduced and postponed in all medical specialties, while the management of urgent cases proceeded unchanged [2]. However, recent publications show that urgent and potentially life-saving procedures and admissions have also been inadvertently reduced, the reasons for such

Availability of data and material

Upon request

Contributors

Study conception, design, analysis and interpretation: PT, drafting of the manuscript: GV, PB and PT. Critical revision of the manuscript for important intellectual content: all authors troublesome findings being likely multifactorial and not yet studied in depth [3-8].

Furthermore, several observational studies have suggested a worrisome reduction in hospitalisations for acute coronary syndromes in the emergency cardiology department in the last few months all over the world $[3,6]$. Especially in older individuals with various co-morbidities in which symptoms of acute coronary events are usually less specific, a delay in diagnosis and lack of appropriate treatment can lead to rapid deterioration and death as well as chronic, long-lasting disabilities [9, 10].

In accordance with the instructions given, the authors' hospital changed its structure as a tertiary hospital and dedicated part of the intensive care unit as well as medical wards to the treatment of severe and mild COVID-19 cases and reduced all non-urgent procedures. The aim of the present study is to assess the impact of the current COVID-19 health crisis on admissions for acute coronary syndrome (ACS) in the emergency cardiology department of a tertiary general hospital in Germany with a COVID-19 ward.

\section{Methods}

The design of the present study is an observational, retrospective analysis of urgent visits and admissions to the authors' emergency cardiology department with ACS during the COVID-19 crisis as compared to equivalent periods in the previous years. Clinical data evaluating consecutive patients with ACS admitted to the cardiological department of $\mathrm{Mu}$ nicipal Hospital of Karlsruhe, Germany, were retrieved. The data were collected for the period between January 1st and June 30th 2020 and equivalent months in the preceding 2 years, including a 5 week period corresponding to this year's COVID-19 outbreak in south-west Germany (23rd March-26th April).

\section{Measurements}

Data were extracted from the hospital's database on all visits to the authors' emergency cardiology department during the aforementioned period according to initial and discharge diagnosis. For the present study, only patients with confirmed ACS at discharge were considered.

\section{Statistical analysis}

Categorical variables were presented as absolute numbers or percentages and compared by chi-squared test adjusted with the Bonferroni method. Lineartrend models were estimated to evaluate differences in admissions during the studied period of time in three differ- 


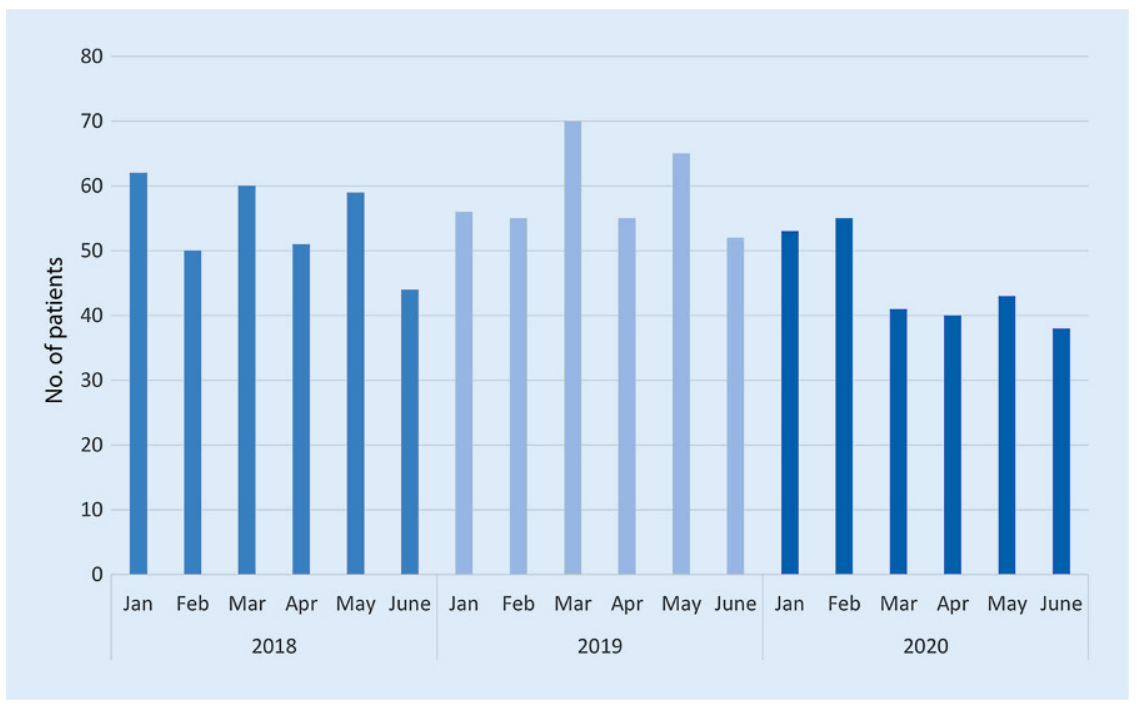

Fig. 1 A Admissions for acute coronary syndrome in January—June 2018, 2019 and 2020

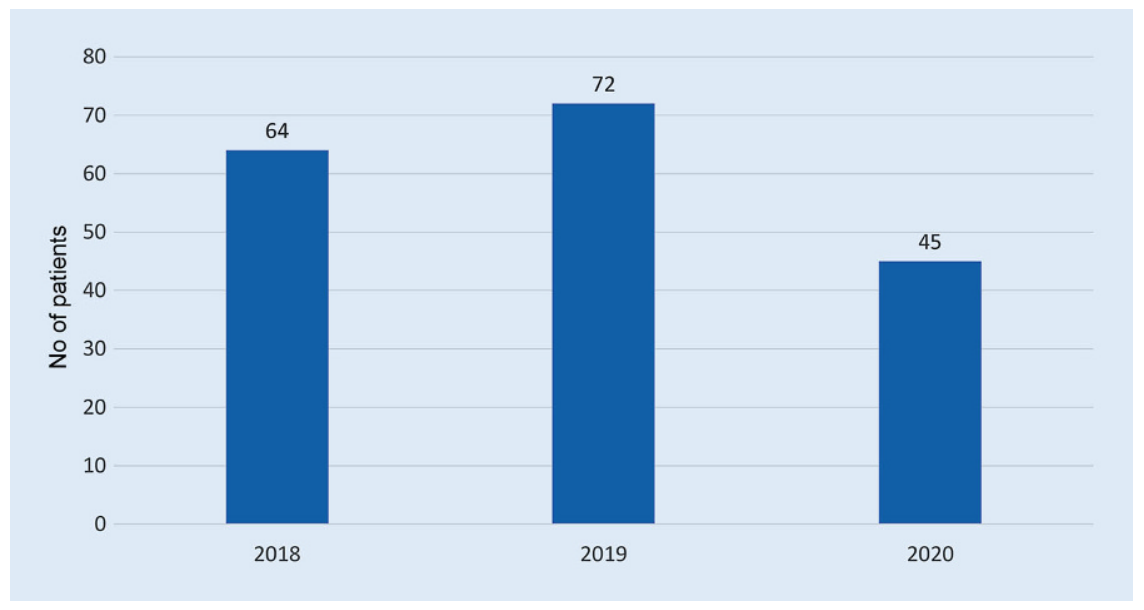

Fig. $2 \Delta$ Admissions for acute coronary syndrome during the COVID-19 surge period in south-west Germany (26th March-26th April 2020) and equivalent period in previous years

ent years (2018, 2019 and 2020) and throughout the same year. All tests were two-sided, and a $p$-value of $<0.05$ was considered statistically significant. Data analyses were conducted using SPSS version 20.0 (IBM, Chicago, IL, USA).

\section{Results}

During the first 6 months of 2020, there were a total of 270 admissions for ACS to the authors' emergency cardiology department. In comparison, in the same period in 2019 and in 2018, admissions for ACS were 353 and 326, respectively, representing a decline of $24 \%$ and $19 \%$. A trend of reduction in admissions for ACS was observed from the beginning of the outbreak in the region at the end of March 2020; in particular, admissions for ACS were 25\% lower in April compared to January 2020 ( $p$-value for linear trend $<0.001)$. The absolute number of admissions in March and April this year was at its absolute lowest compared to any other month in the previous 3 years (• Fig. 1). This trend continued and even intensified after a reduction of COVID19 cases in the area: in May 2020, the number of patients with ACS was 19\% and in June $29 \%$ lower than in January 2020 ( $p$-value for linear trend <0.001). A similar trend was not observed in previous years (• Fig. 1).

Considering the 5 -week period of the COVID-19 outbreak in south-west Ger- many, an even more significant and consistent reduction was observed compared with equivalent periods in the previous 2 years (38\% and 30\% lower than in 2019 and 2018, respectively; $p$-value $=0.009$ ) (• Fig. 2).

Finally, the total number of coronary angiographies and percutaneous coronary interventions performed in the authors' cardiology department was $41 \%$ and $42 \%$, respectively, lower than in 2019 ( $p$-value $<0.001$ for both years) and 31\% and $42 \%$, respectively, than in 2018 ( $p$ value $<0.001$ for both years) (• Fig. 3).

\section{Discussion}

The main finding of the present study is the dramatic reduction in the number of hospitalizations for ACS at the authors' hospital during and after this year's COVID-19 outbreak. This phenomenon started as COVID-19 cases increased and continued with increased significance even as the outbreak faded.

The authors' hospital is a tertiary medical facility which provides advanced medical care for the population of the city of Karlsruhe and its sub-urban area (ca. 450,000 people). The cardiology department in this study includes a 12bed intensive care unit, a 12-bed cardiac care unit and a 22-bed sub-intensive care unit.

The first case in the region was reported on the 28th of February, while the outbreak peaked at the end of the month [11]. The German government enforced quarantine measures including limitations on public and working activities, as well state school closure on 24th of March [12]. In compliance with the enforced measures, the authors postponed all elective, deferrable activities on the 28th of March until the 26th of April, and a significant part of their resources was shifted to the management of severe and mild COVID-19 cases.

An initial evaluation of visits to their emergency department included vital parameters (i.e. blood pressure, temperature, oxygen saturation), as well as a standard 12-channel electrocardiogram and a brief medical history. Patients with signs and symptoms suspicious for respiratory infectious diseases 
Herz 2020 • 45:663-667 https://doi.org/10.1007/s00059-020-04991-3

(c) Springer Medizin Verlag GmbH, ein Teil von Springer Nature 2020

\section{G. Vacanti · P. Bramlage · G. Schymik · C. Schmitt · A. Luik · P. Swojanowsky · P. Tzamalis}

\section{Reduced rate of admissions for acute coronary syndromes during the COVID-19 pandemic: an observational analysis from a tertiary hospital in Germany}

\section{Abstract}

Background. Several observational studies have suggested a worrying reduction in hospitalisations for acute coronary syndromes in the emergency cardiology department in the last few months all over the world. The aim of the present study is to assess the impact of the current COVID-19 health crisis on admission for acute coronary syndrome (ACS) in the cardiology department of a tertiary general hospital in Germany with a COVID-19 ward.

Methods and results. The authors retrieved clinical data evaluating consecutive patients with ACS admitted to their emergency cardiology department. Data from January to June 2020, as well as for a 5-week period corresponding to this year's COVID-19 outbreak in south-west Germany (23rd March-26th April), were analysed and compared to data from equivalent weeks in the previous 2 years. A trend of reduction in admissions for ACS was observed from the beginning of the outbreak in the region at the end of March 2020. This trend continued and even intensified after a fall in COVID19 cases in the area; the number of ACS patients in April 2020 was $25 \%$ and in June $29 \%$ lower than in January 2020 ( $p$-value for linear trend $<0.001$ ). An even more consistent reduction was observed as compared with the equivalent weeks in the previous 2 years
(38\% and 30\% lower than in 2019 and 2018, respectively; $p=0.009$ ).

Conclusions. The COVID-19 health and social crisis has caused a worrying trend of reduced cardiological admissions for ACS, without evidence of a decrease in its incidence. Understanding and counteracting the causes appears to be crucial to avoiding major longterm consequences for healthcare systems worldwide.

Keywords

Myocardial infarction · Percutaneous coronary intervention - Acute coronary events · SARSCoV-2 Coronary angiography

\section{Seltenere Aufnahmen wegen eines akuten Koronarsyndroms während der COVID-19-Pandemie - eine Beobachtungsstudie an einem deutschen Krankenhaus der Tertiärversorgung}

Zusammenfassung

Hintergrund. Mehrere Beobachtungsstudien weisen auf einen besorgniserregenden Rückgang der Hospitalisierungen wegen eines akuten Koronarsyndroms (ACS) in kardiologischen Notaufnahmen über die vergangenen Monate hin - und das weltweit. Ziel der vorliegenden Studie war es, die Auswirkungen der gegenwärtigen COVID19-Gesundheitskrise auf die Aufnahmen wegen ACS in der kardiologischen Abteilung eines deutschen Krankenhauses der Tertiärversorgung mit COVID-19-Station zu untersuchen.

Methoden und Ergebnisse. Ausgewertet wurden klinische Daten konsekutiver Patienten mit ACS, die in der kardiologischen Notaufnahme der Autoren behandelt worden waren. Daten von Januar bis Juni 2020 sowie aus einer 5 -wöchigen Phase, die den diesjährigen COVID-19-Ausbruch in Südwestdeutschland abdeckt (23. März bis 26. April), wurden analysiert und mit Daten aus den entsprechenden Wochen der beiden Vorjahre verglichen. Ein Trend zu reduzierten Aufnahmen wegen ACS zeigte sich ab Beginn des Ausbruchs in der Region Ende März 2020. Dieser Trend hielt an und verstärkte sich nach einem Abfall der COVID19-Fälle in der Region sogar; die Zahl der Patienten mit ACS war im April 2020 25\% und im Juni $29 \%$ niedriger als im Januar 2020 ( $p$-Wert für linearen Trend $<0,001$ ). Eine noch beständigere Reduktion zeigte sich im Vergleich mit den entsprechenden Wochen in den beiden Vorjahren (38\% und 30\% niedriger als 2019 bzw. 2018; $p=0,009$ ). Schlussfolgerungen. Die gesundheitliche und gesellschaftliche Krise durch COVID-19 hat zu einem besorgniserregenden Rückgang kardiologischer Aufnahmen wegen ACS geführt, ohne dass es Hinweise auf eine reduzierte Inzidenz geben würde. Es erscheint von wesentlicher Bedeutung, die Ursachen zu verstehen und ihnen entgegenzuwirken, um schwerwiegende Langzeitfolgen für Gesundheitssysteme weltweit zu vermeiden.

Schlüsselwörter

Myokardinfarkt · Perkutane Koronarintervention - Akute koronare Ereignisse - SARS-CoV-2 . Koronarangiographie underwent imaging screening of the lung (i.e. radiography or computed tomography scan), as well as swab testing for SARS-COV-2, and remained isolated in the authors' COVID-19 area until test results were available. In the case of ST-elevation myocardial infarction (STEMI) with suspected COVID-19, the protocol dictates immediate cardiac catheterization in a dedicated catheter laboratory with all protective measures in place, including proper negative pres- sure room ventilation and personal protective devices such as FFP-3 face masks, in accordance with guidelines of the German Society of Cardiology [13]. With regard to door-to-balloon intervals, a possible delay in care delivery has been observed in the current literature [5], while other studies showed no significant delay in ACS management throughout the STEMI Network in Germany, and as the authors' managing protocols did not change during the outbreak, they do not expect a significant delay to have taken place in their hospital [2].

The total number of cardiac catheterisations and percutaneous coronary interventions with stenting was also significantly reduced. This could be partially due to a combination of reduced hospitalisations for acute cardiological diseases and of lack of elective procedures in the authors' cardiological department during the outbreak. 


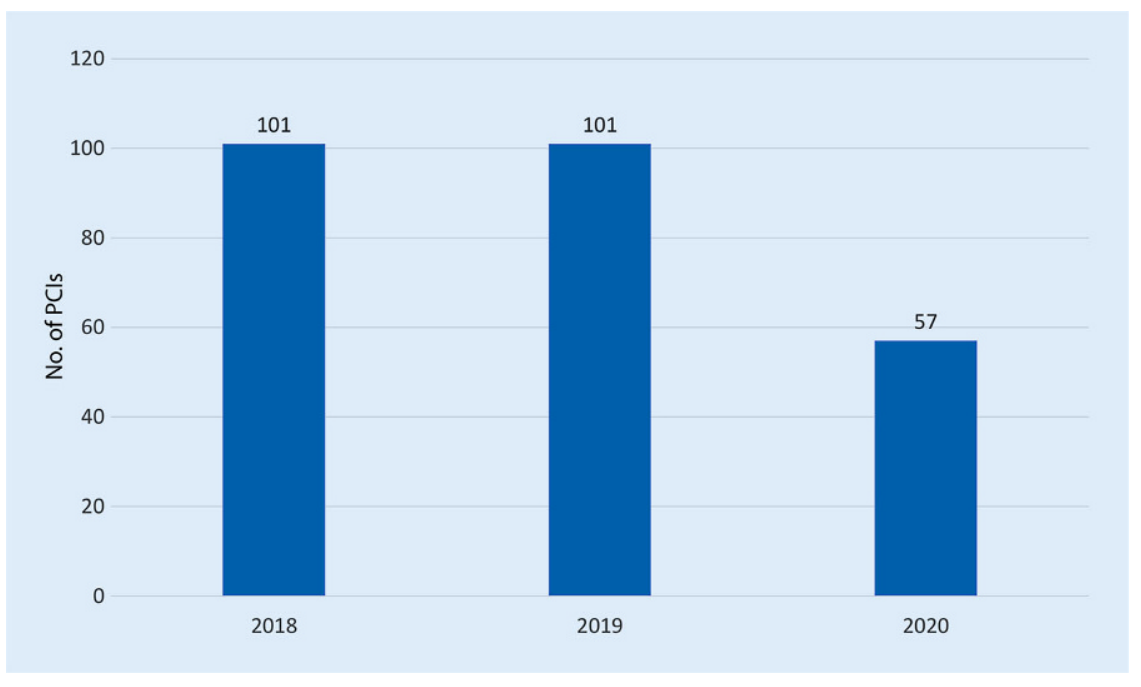

Fig. $3 \Delta$ Percutaneous coronary interventions (PCI) during the COVID-19 surge period in south-west Germany (26th March-26th April 2020) and equivalent period in previous years

Although a link between viral infections and, more specifically, between coronaviruses and acute cardiovascular events has been known and well established [13-15], many recent studies, in agreement with the present findings, point to a significant reduction in hospitalisations for such events [3-7]. A large multi-centre study in Italy recorded a reduction of up to $59 \%$ in admissions for ACS during the peak of the outbreak in Italy compared to equivalent periods in the previous years [6]. Similar observations were reported in Spain, the United States, Austria and China $[4,7,16,17]$.

Many studies have been conducted to investigate this phenomenon $[6,13,18]$. First, the fear of contagion at the hospital may have discouraged access to emergency medical facilities. The fact that the reduction in admissions at the authors' facilities continued, and even became more consistent as the number of COVID19 cases dropped and the government loosened quarantine measures, suggests that this psychological element may represent an important factor. This may imply a troublesome increase in elapsed, non-treated ACS in the general population that did not seek medical attention. This appears to also apply to non-cardiological acute diseases. In concordance with this hypothesis, Kristoffersen et al. demonstrated not only that the admissions for acute stroke in a Norwegian hospital decreased during the COVID-19 outbreak, but also the severity of the disease was more significant than in previous years, suggesting either that patients with mild forms of the disease did not seek medical attention at all or that they waited until worsening of the symptoms before seeking medical help [8]. The extent of such non-treated cases and their effect on public health will become apparent in the near future, when data on general mortality during the COVID-19 outbreak and on rates of post-myocardial infarction heart failure and arrhythmias become available $[9,10]$. A second hypothesis is linked to the fact that the authors cannot completely exclude the possibility that a true reduction in the incidence of ACS as a potential beneficial result of low mental and physical stress during the quarantine might have partially contributed to the lower number of admissions to the emergency cardiology department in question [19]. Although data on the current COVID-19 outbreaks are not yet available, Wang etal. showed how people undergoing quarantine during the H1N1 2009 outbreak in China did not suffer from more stressful experiences than people not affected by quarantine measures [20]. On the other hand, arterial and venous thromboembolic events and cases of disseminated intravascular dissemination have been described in the recent literature, as COVID-19 is associated with an inflammatory status characterised by coagula- tion activation and endothelial dysfunction [21-23].

Finally, the fact that the emergency medical system was focused on COVID19 and healthcare resources were reallocated to manage the pandemic may have largely contributed to the reduction in emergency cardiological admissions. This might have induced an attitude towards deferral of less urgent cases, at both the patient and the healthcare system levels. Other studies have also pointed in this direction: De Rosa et al., for example, showed how in Italy, in spite of a significant overall reduction in hospitalisations for ACS, the reduction for STEMI was less striking than that for NSTEMI [6]. Of note, this may also be true for the inhospital management of ACS patients. In fact, at the authors' hospital the number of total catheterisations and percutaneous coronary interventions in the catheterisation laboratory dropped significantly, showing a tendency to postpone nonurgent, deferrable cases during the outbreak.

Despite a reallocation of resources and beds in the cardiac intensive care unit in this study to address the COVID-19 outbreak, the reduction in admissions for ACS does not seem to be linked to the lack of non-COVID-19 beds, as intensive care beds in the non-COVID-19 area remained continuously available.

\section{Limitations}

The study has a number of limitations given that this is a retrospective analysis of the admissions to a hospital and, therefore, no data are available on the clinical characteristics or implications of those patients.

\section{Conclusions}

In conclusion, the COVID-19 health and social crisis has caused a worrisome trend of reduced cardiological admissions for ACS, without evidence of a decrease in its incidence. Understanding and counteracting the causes for this appears to be crucial in order to avoid major and long-standing consequences for healthcare systems worldwide. 


\section{Corresponding address}

\section{Dr. Panagiotis Tzamalis, MD}

Medical Clinic IV—Department of Cardiology,

Municipal Hospital Karlsruhe, Academic Teaching Hospital of the University of Freiburg Moltkestr. 90, 76133 Karlsruhe, Germany tzamalisp@gmail.com panagiotis.tzamalis@klinikum-karlsruhe.de

\section{Compliance with ethical guidelines}

Conflict of interest. G. Vacanti, P. Bramlage, G. Schymik,C. Schmitt, A. Luik, P. Swojanowsky and $P$. Tzamalis declare that they have no competing interests.

For this article no studies with human participants or animals were performed by any of the authors. All studies performed were in accordance with the ethical standards indicated in each case.

\section{References}

1. Li Q, Guan X, Wu P, Wang X, Zhou L, Tong Y, Ren R, Leung KSM, Lau EHY, Wong JY, Xing $X$, Xiang N, Wu Y, Li C, Chen Q, Li D, Liu T, Zhao J, Liu M, Tu W, Chen $C$, Jin $L$, Yang R, Wang $Q$, Zhou S, Wang R, Liu H, Luo Y, Liu Y, Shao G, Li H, Tao Z, Yang Y, Deng Z, Liu B, Ma Z, Zhang Y, Shi G, Lam TTY, Wu JT, Gao GF, Cowling BJ (2020) Early transmission dynamics in Wuhan, China, of novel coronavirus-infected. Pneumonia 382(13):1199-1207. https://doi.org/ 10.1056/NEJMoa2001316

2. Scholz $\mathrm{KH}$, Lengenfelder $B$, Thilo $C$, Jeron $A$, Stefanow S, Janssens U, Bauersachs J, Schulze PC, Winter KD, Schröder J, Vom Dahl J, von Beckerath N, Seidl K, Friede T (2020) Impact of COVID-19 outbreak on regional STEMI care in Germany. Clin Res Cardiol. https://doi.org/10.1007/s00392-02001703-z

3. Tsioufis K, Chrysohoou C, Kariori M, Leontsinis I, Dalakouras I, Papanikolaou A, Charalambus G, Sambatakou H, Siasos G, Panagiotakos D, Tousoulis D (2020) The mystery of "missing" visits in an emergency cardiology department, in the era of COVID-19.; a time-series analysis in a tertiary Greek general hospital. Clin Res Cardiol. https://doi.org/ 10.1007/s00392-020-01682-1

4. Garcia S, Albaghdadi MS, Meraj PM, Schmidt C, Garberich R, Jaffer FA, Dixon S, Rade JJ, Tannenbaum $M$, Chambers J, Huang PP, Henry TD (2020) Reduction in ST-segment elevation cardiac catheterization laboratory activations in the United States during COVID-19 pandemic. J Am Coll Cardiol 75(22):2871-2872. https://doi.org/10. 1016/j.jacc.2020.04.011

5. Tam CF, Cheung KS, Lam S, Wong A, Yung A, Sze M, Lam YM, Chan C, Tsang TC, Tsui M, Tse HF, Siu CW (2020) Impact of coronavirus disease 2019 (COVID19) outbreak on ST-segment-elevation myocardial infarction care in Hong Kong, China. Circ Cardiovasc Qual Outcomes 13(4):e6631. https:// doi.org/10.1161/circoutcomes.120.006631

6. De Rosa S, Spaccarotella C, Basso C, Calabrò MP, Curcio A, Filardi PP, Mancone M, Mercuro G,
Muscoli S, Nodari S, Pedrinelli R, Sinagra G, Indolfi C (2020) Reduction of hospitalizations for myocardial infarction in Italy in the COVID-19 era. Eur Heart J 41(22):2083-2088. https://doi.org/10. 1093/eurheartj/ehaa409

7. Metzler B, Siostrzonek P, Binder RK, Bauer A, Reinstadler SJ (2020) Decline of acute coronary syndrome admissions in Austria since the outbreak of COVID-19: the pandemic response causes cardiac collateral damage. Eur Heart J 41(19):1852-1853. https://doi.org/10.1093/ eurheartj/ehaa314

8. Kristoffersen ES, Jahr SH, Thommessen B, Rønning OM (2020) Effect of COVID-19 pandemic on stroke admission rates in a Norwegian population Acta Neurol Scand. https://doi.org/10.1111/ane. 13307

9. Scholz KH, Maier SKG, Maier LS, Lengenfelder B, Jacobshagen C, Jung J, Fleischmann C, Werner GS, Olbrich HG, Ott R, Mudra H, Seidl K, Schulze PC, Weiss C, Haimerl J, Friede T, Meyer T (2018) Impac of treatment delay on mortality in ST-segment elevation myocardial infarction (STEMI) patients presenting with and without haemodynamic instability: results from the German prospective, multicentre FITT-STEMI trial. Eur Heart J 39(13):1065-1074. https://doi.org/10.1093/ eurheartj/ehy004

10. Zhang B, Shen DP, Zhou XC, Liu J, Huang RC, Wang YE, Chen AM, Zhu YR, Zhu H (2015) Long-term prognosis of patients with acute non-ST-segment elevation myocardial infarction undergoing different treatment strategies. Chin Med J 128(8):1026-1031. https://doi.org/10.4103/ 0366-6999.155071

11. ka-news (2020) Erster Corona-Fall in Karlsruhe bestätigt: Geschäftsreisender aus Nürnberg, Hotlinefür Bürger aktiv

12. Bundesministerium für Gesundheit (2020) Coronavirus SARS-CoV-2: Chronik der bisherigen Maßnahmen

13. Böhm M, Frey N, Giannitsis E, Sliwa K, Zeiher AM (2020) Coronavirus disease 2019 (COVID-19) and its implications for cardiovascular care: expert document from the German cardiac society and the world heart federation. Clin Res Cardiol. https://doi.org/10.1007/s00392-020-01656-3

14. Yu CM, Wong RS, Wu EB, Kong SL, Wong J, Yip GW, Soo YO, Chiu ML, Chan YS, Hui D, Lee N, Wu A, Leung CB, Sung JJ (2006) Cardiovascular complications of severe acute respiratory syndrome. Postgrad Med J 82(964):140-144. https://doi.org/ 10.1136/pgmj.2005.037515

15. Liu PP, Blet A, Smyth D, Li H (2020) The science underlying COVID-19: implications for the cardiovascular system. Circulation 142(1):68-78. https:// doi.org/10.1161/circulationaha.120.047549

16. Li B, Yang J, Zhao F, Zhi L, Wang X, Liu L, Bi Z, Zhao Y (2020) Prevalence and impact of cardiovascular metabolic diseases on COVID-19 in China. Clin Res Cardiol 109(5):531-538. https://doi.org/10.1007/ s00392-020-01626-9

17. Rodriguez-Leor O, Cid-Alvarez B (2020) STsegment elevation myocardial infarction care during COVID-19. Losing sight of the forest for the trees. JACC Case Rep 2(10):1625-1627. https://doi. org/10.1016/j.jaccas.2020.04.011

18. Katz JN, Sinha SS, Alviar CL, Dudzinski DM, Gage A, Brusca SB, Flanagan MC, Welch T, Geller BJ, Miller PE, Leonardi S, Bohula EA, Price $S$ Chaudhry SP, Metkus TS, O'Brien CG, Sionis A, Barnett CF, Jentzer JC, Solomon MA, Morrow DA, van Diepen S (2020) COVID-19 and disruptive modifications to cardiac critical care delivery: JACC review topic of the week. J Am Coll Cardiol 76(1):72-84. https://doi.org/10.1016/j.jacc.2020. 04.029

19. Wirtz PH, von Känel R (2017) Psychological stress, inflammation, and coronary heart disease. Curr Cardiol Rep 19(11):111. https://doi.org/10.1007/ s11886-017-0919-X

20. Wang Y, Xu B, Zhao G, Cao R, He X, Fu S (2011) Is quarantine related to immediate negative psychological consequences during the 2009 H1N1 epidemic? Gen Hosp Psychiatry 33(1):75-77. https://doi.org/10.1016/j.genhosppsych.2010.11. 001

21. Lodigiani C, lapichino $G$, Carenzo L, Cecconi M, Ferrazzi P, Sebastian T, Kucher N, Studt JD, Sacco C, Alexia B, Sandri MT, Barco S (2020) Venous and arterial thromboembolic complications in COVID19 patients admitted to an academic hospital in Milan, Italy. Thromb Res 191:9-14. https://doi.org/ 10.1016/j.thromres.2020.04.024

22. Klok FA, Kruip M, van der Meer NJM, Arbous MS, Gommers D, Kant KM, Kaptein FHJ, van Paassen J, Stals MAM, Huisman MV, Endeman H (2020) Incidence of thrombotic complications in critically ill ICU patients with COVID-19. Thromb Res 191:145-147. https://doi.org/10.1016/j.thromres. 2020.04.013

23. Varga $Z$, Flammer AJ, Steiger $P$, Haberecker $M$, Andermatt R, Zinkernagel AS, Mehra MR, Schuepbach RA, Ruschitzka F, Moch H (2020) Endothelial cell infection and endotheliitis in COVID-19. Lancet 395(10234):1417-1418. https://doi.org/10.1016/ s0140-6736(20)30937-5 